\title{
Solvent Extraction Studies for Separation of Zn(II) and Mn(II) from Spent Batteries Leach Solutions
}

\author{
Lorena Falco, ${ }^{1,2}$ Margarida J. Quina, ${ }^{1}$ Licínio M. Gando-Ferreira, ${ }^{1}$ \\ Horacio Thomas, ${ }^{2}$ and Gustavo Curutchet ${ }^{3}$ \\ ${ }^{1}$ Department of Chemical Engineering, Center of Chemical Processes Engineering and Forest \\ Products (CIEQPF), University of Coimbra, Rua Silvio Lima, Coimbra, Portugal \\ ${ }^{2}$ Pla.Pi.Mu. Planta Piloto Multipropósito, Comisión de Investigaciones Científicas Prov. de Buenos \\ Aires, Argentina \\ ${ }^{3}$ Escuela de ciencias y Tecnología Universidad de San Martín, Argentina
}

This study aims at assessing the possibility of using solvent extraction processes for separating $\mathrm{Zn}$ (II) and $\mathrm{Mn}$ (II) dissolved in aqueous solutions obtained by acid bioleaching of spent alkaline and $\mathrm{Zn}-\mathrm{C}$ batteries. In this context, Cyanex 272 and DEHPA were tested as extractant agents, and the former was shown to have better performance. Hence, the effect of four factors (equilibrium $\mathrm{pH}$, extractant concentration, $\mathrm{A} / \mathrm{O}$ ratio, and temperature) into three response variables (extraction efficiency of $\mathrm{Zn}, \mathrm{Y}_{\mathrm{Zn}}$; extraction efficiency of $\mathrm{Mn}, \mathrm{Y}_{\mathrm{Mn}}$; separation factor, $\beta$ ) were tested according to a full factorial design $\left(2^{4}\right)$ with two replicated center points. Our study revealed that $Y_{\mathrm{Zn}}$ depends mainly on the extractant concentration, $\mathrm{Y}_{\mathrm{Mn}}$ on the equilibrium $\mathrm{pH}$ and $\beta$ on the equilibrium $\mathrm{pH}$, extractant concentration, and $\mathrm{A} / \mathrm{O}$ ratio as well as on second and third order interactions. One extraction step is sufficient to reach high extraction of zinc in synthetic solutions, but two stages were required for real leaching liquor. The extraction kinetics is fast (less than $15 \mathrm{~min}$ ) for both metals, even when real liquor was tested. The organic solvent can be efficiently recovered using a stripping solution of $\mathrm{H}_{2} \mathrm{SO}_{4} 1 \mathrm{M}$ and thus the process can be considered environmentally sustainable.

Keywords Cyanex 272; DEHPA; design of experiments; solvent extraction; spent batteries

\section{INTRODUCTION}

In recent years, there has been a growing consumption of batteries mainly driven by a new generation of electronic devices, such as digital cameras, camera phones, and high performance portable computing devices. The European Union market for batteries and accumulators is estimated

Received 14 December 2012; accepted 27 September 2013.

Address correspondence to Licínio M. Gando-Ferreira, Center of Chemical Processes Engineering and Forest Products (CIEQPF), Department of Chemical Engineering, University of Coimbra, Rua Sílvio Lima, Coimbra 3030-790, Portugal. E-mail: lferreira@eq.uc.pt

Color versions of one or more of the figures in the article can be found online at www.tandfonline.com/lsst. to be $800,000 \mathrm{t}$ of automotive batteries, $190,000 \mathrm{t}$ of industrial batteries, and 160,000 $\mathrm{t}$ of portable batteries each year (1). The disposal of spent batteries may represent a serious environmental threat due to its high content of heavy metals. Mercury, lead, and cadmium are examples of the most toxic metals potentially present in batteries. The Directive 2006/66/EC of the European Parliament and of the Council aims to cut the amount of hazardous metals (e.g., $\mathrm{Hg}, \mathrm{Cd}$, and $\mathrm{Pb}$ ) dumped in the environment and thus it prohibits the ultimate disposal of portable industrial and automotive batteries and accumulators by incineration or landfill. In addition, there is a prohibition of the Member States on placing on the market:

i. all batteries which contain more than $0.0005 \%$ of mercury by weight; and

ii. portable batteries or accumulators which contain more than $0.002 \%$ of cadmium by weight.

This directive also established some restrictions for lead, and in some cases a limit of $0.004 \%$ is indicated. This and other regulations are important drivers for the collection of spent batteries and recovery of metals for reuse. The recycling of batteries in order to recover metals is a sustainable way to reduce the environmental impact of such waste. The 15 members of EBRA (European Battery Recycling Association) in 2004 recycled approximately 23,900 t of portable batteries and accumulators, of which $85 \%$ were alkaline, zinc-carbon, and zinc-air batteries (2). On the contrary, in countries such as Argentina, batteries are sent with the rest of the domestic garbage to landfills, while a small portion of nickel-cadmium batteries are treated by a pyrometallurgical method.

Several methods to separate metals from spent batteries for reuse are reported in the literature (3). The pyrometallurgical and/or hydrometallurgical processes are the most often used at industrial scale. The pyrometallurgical 
process involves high operational costs and basically comprises the selective volatilization of metals at high temperatures followed by condensation, and some emissions of dust and gases are expected. The hydrometallurgical process is economically more attractive and in general it is characterized by different steps of pre-treatment followed by leaching and metal separation (4). The recovery of zinc and manganese can be achieved from the acid leach solution by using chemical precipitation (5-10), electrochemical processes $(11,12)$, and solvent extraction $(9,13-16)$. An important disadvantage of the first two processes is the low purity of the final solutions. However, solvent extraction processes have the advantages of requiring easy operation, low energy consumption, and good performance, thereby enabling the metal recovery at high purity. In this case, the main drawback is the cost of the solvent that may render the extraction system expensive. Even so, the solvent can be recovered for reuse and consequently the costs might be reduced.

The solvent extraction process is an emerging technique for the recovery of zinc from effluents containing low metallic value. Extraction of zinc from sulphate solutions using alkyl carboxylic, phosphoric, and phosphonic acids was reported in several works (13-20) comparing the behavior of different commercial extractants: Cyanex 302 [bis(2,4,4-trimethylpentyl) monothiophosphonic acid], DEHPA [Di-(2-ethylhexyl) phosphoric acid] and Cyanex 272 [bis-(2,4,4-trimethylpentyl) phosphinic acid]. The organic loaded zinc phase was stripped with sulphuric acid or hydrochloric acid and then solvents can be reused.

It was reported that DEHPA is used for the separation of zinc from cobalt contained in leaching solution of raw materials (21). It is also documented that synergistic separation of zinc and manganese from sulphate solutions can be carried out with sodium salts of the extractants DEHPA, PC 88A (2-Ethylhexyl 2-ethylhexyphosphonic acid) and Cyanex 272, finding that extraction of metal ions increased with an increase of the equilibrium $\mathrm{pH}$, and extractant concentration (21). The use of calcium loaded organic acid extractants like DEHPA in Exsol D80 (diluent), a mixture of Cyanex 272 and LIX 84-I (2Hydroxy-5-nonylacetophenone oxime), Cyanex 272 in Exsol D80 (diluent) for the extraction of the metal ions $\mathrm{Al}, \mathrm{Fe}, \mathrm{Hg}, \mathrm{Cu}, \mathrm{Zn}, \mathrm{Ni}, \mathrm{Co}, \mathrm{Mn}, \mathrm{Pb}$, and $\mathrm{Cd}$ from aqueous solution is patented (22). Jha and co-workers (23) tested the use of Cyanex 272 and Cyanex 302, both at a concentration of $5 \%$ diluted in kerosene with $1 \%$ isodecanol, for the extraction of zinc from aqueous solution containing calcium and zinc, produced in the rayon industry, reaching an extraction of about $99 \%$ of the zinc, at equilibrium $\mathrm{pH} 3$ and $\mathrm{O} / \mathrm{A}$ ratio of $4: 1$.

The powder extracted after the dismantling of the alkaline and zinc-carbon batteries contains an expressive amount of $\mathrm{Zn}(\mathrm{II})$ and $\mathrm{Mn}(\mathrm{II})$, which can represent about
$66 \%$ of the total mass (12), as well as impurities such as $\mathrm{Pb}, \mathrm{Cd}$, and $\mathrm{Fe}$ that are present at low concentrations. Devi and co-workers (13) investigated the solvent extraction of zinc and manganese from sulphate solutions using Cyanex 272 (bis-2,4,4-trimethylpentyl phosphinic acid) and they found a maximum separation factor of 6000 at $\mathrm{pH} 5.2$ for $\mathrm{Zn}(\mathrm{II})$ over $\mathrm{Mn}(\mathrm{II})$. The same extractant was used by Salgado et al. (14) for separating $\mathrm{Zn}$ (II) and $\mathrm{Mn}$ (II) from spent alkaline batteries. They demonstrated through bench scale experiments that zinc and manganese were easily separated using 20\% (v/v) Cyanex 272 dissolved in Escaid 110 at $50^{\circ} \mathrm{C}$.

Hydrometallurgy applied to spent batteries recycling is versatile enough to be used to treat other similar waste materials such as metal-containing sludge, dusts, or spent catalysts. Solvent extraction can even play a key role, allowing the manufacture of high purity products. In this work, a hydrometallurgical route based on the liquid-liquid extraction was evaluated for the separation and subsequent recovery of metals contained in synthetic and also in real leach solutions obtained from a biohydrometallurgical process for the leaching of zinc and manganese from spent zinc-carbon and alkaline battery powders. Biohydrometallurgy can be defined as the field of applications resulting from the control of natural (biochemical) processes of interactions between microbes and minerals to recover valuable metals $(24,25)$. Commercial applications of biohydrometallurgy have advanced due to favorable process economics, and in some cases reduced environmental problems compared to conventional metal recovery processes such as smelting (26). Cerruti et al. (27) studied a biohydrometallurgical method for the recovery of metals from spent $\mathrm{Ni}-\mathrm{Cd}$ batteries using Acidithiobacillus thiooxidans, and concluded that a high recovery of these metals can be achieved.

The synthetic spent battery leachate solutions tested in our study contained zinc and manganese in similar concentrations to those leaving a biohydrometallurgical process carried out in a pilot plant built in Pla.Pi.Mu. (Multipurpose Pilot Plant), Universidad Nacional de La Plata, Argentina, where Acidithiobacillus thioxidans were cultivated. Biofilm reactors with $A$. thiooxidans on elemental sulphur have been used to reach high sulphuric acid productivity $(28,29)$. Acidithiobacillus thiooxidans is a bacterium able to catalyze the oxidation of elemental sulphur and other reduced sulphur compounds to polythionates and sulphuric acid (30). It requires a minimal mineral medium and is easily cultivated in the laboratory. It reveals a remarkable tolerance to heavy metals and low $\mathrm{pH}$ condition.

The present study aimed at analyzing the solvent extraction process for separating $\mathrm{Zn}(\mathrm{II})$ and $\mathrm{Mn}$ (II) by testing two commercial extractants. After the initial selection of the extractant, a full factorial design was applied to screen the significant factors and their interactions. In addition, equilibrium, kinetic, and stripping studies were also 
conducted to obtain an overall assessment of the process. It is worth mentioning that few works are reported in the literature on the application of factorial design in the planning of experiments for the separation of metal ions from solutions using extraction solvent.

\section{EXPERIMENTAL}

\section{Solutions and Reagents}

A synthetic aqueous solution of $\mathrm{ZnSO}_{4} \cdot 7 \mathrm{H}_{2} \mathrm{O}$ and $\mathrm{MnSO}_{4} \cdot \mathrm{H}_{2} \mathrm{O}$ containing $6 \mathrm{~g} / \mathrm{L}$ of $\mathrm{Zn}(\mathrm{II})$ and $1.5 \mathrm{~g} / \mathrm{L}$ of $\mathrm{Mn}(\mathrm{II})$ were prepared and used in the subsequent extraction tests. Two different extractants were tested: Cyanex 272 (bis 2,4,4-trimethylpentyl phosphoric acid), kindly provided by Cytec Canada and Cytec Chile; and DEHPA [di(2-ethyl-hexyl)phosphoric acid] obtained from Sigma. The extractants were used as received without further purification. Both extractants were diluted in kerosene. Solutions of $\mathrm{NH}_{4} \mathrm{OH}$ (1:10) and $0.1 \mathrm{M} \mathrm{H}_{2} \mathrm{SO}_{4}$ were used for $\mathrm{pH}$ adjustment. A stripping solution of $1 \mathrm{M} \mathrm{H}_{2} \mathrm{SO}_{4}$ was utilized for the solvent recovery.

Samples of real leaching liquor from a biohydrometallurgical process for the recycling of spent alkaline and $\mathrm{Zn}-\mathrm{C}$ batteries (briefly described in the section immediately following this one), were used for kinetic and equilibrium extraction experiments. The chemical composition of this leaching liquor is shown in Table 1, and it is visible that $\mathrm{Zn}(\mathrm{II})$ and $\mathrm{Mn}(\mathrm{II})$ are in high concentrations in comparison to other metals.

\section{Biohydrometallurgical Process for the Treatment of Spent Batteries}

The biohydrometallurgical process for the recycling of metals from spent alkaline and zinc-carbon batteries consisted in three steps occurring in a bioreactor, a leaching unit, and a recovery unit. An air-lift bioreactor was used for cultivating Acidithiobacillus thiooxidans bacteria in $0 \mathrm{~K}$ medium with a sulphur-packed bed. These chemoautotrophic bacteria use $\mathrm{CO}_{2}$ from the air as carbon source and an inorganic reduced compound (sulphur in this work) as an energy source. Sulphur is oxidized by Acidithiobacillus thiooxidans to sulphuric acid and other reducing compounds and this acid-reducing medium was further used in the leaching process.

The leaching unit is a stirred tank where the acid reducing medium produced in the bioreactor is mixed with the

TABLE 1

Chemical composition of the spent alkaline and $\mathrm{Zn}-\mathrm{C}$ batteries leaching liquor

\begin{tabular}{ccccccc}
\hline & $\mathrm{Mn}$ & $\mathrm{Zn}$ & $\mathrm{Pb}$ & $\mathrm{Cd}$ & $\mathrm{Fe}$ & $\mathrm{Ni}$ \\
\hline Concentration (ppm) & 1400 & 6500 & 1.33 & 0.2 & 843 & 5.5 \\
\hline
\end{tabular}

battery powder, previously washed several times with deionized water in order to eliminate the electrolyte. In this unit, zinc and part of manganese contained in the batteries were leached with an efficiency of about 90 and $20 \%$, respectively, and thus a solution of manganese sulphate and zinc sulphate was produced. The solid remaining after leaching was mainly manganese oxide that did not react with the acid reducing media mixed with carbon.

In the recovery unit, zinc and manganese were separated from the solution for reuse. Three alternatives were studied for this unit, electrolysis, selective precipitation, and solvent extraction. In this work the third alternative was studied-solvent extraction, as it is described below.

\section{Solvent Extraction Procedures and Analytical Techniques}

The extraction experiments were carried out by contacting the aqueous $(\mathrm{A})$ and organic $(\mathrm{O})$ phases in separatory funnels at suitable $(\mathrm{A} / \mathrm{O})$ volume ratios. The funnels were kept in a shaker at constant temperature $\left(25\right.$ or $\left.50^{\circ} \mathrm{C}\right)$ for $15 \mathrm{~min}$. This time was considered long enough to achieve the equilibrium conditions according to preliminary tests.

The experiments for the selection of the extractant were performed at $25^{\circ} \mathrm{C}$ and $\mathrm{A} / \mathrm{O}$ ratio of 1.0. The concentration of Cyanex 272 was of $0.5 \mathrm{M}$ and DEHPA of $1 \mathrm{M}$. Different equilibrium $\mathrm{pH}$ were tested, being the $\mathrm{pH}$ of the solution adjusted by adding drops of $\mathrm{NH}_{4} \mathrm{OH}(1: 10)$ or $1 \mathrm{M} \mathrm{H}_{2} \mathrm{SO}_{4}$ solution as necessary.

Stripping tests for the recovery of metals from organic phase (and consequently the solvent recycling) were carried out with $\mathrm{H}_{2} \mathrm{SO}_{4} 1 \mathrm{M}$ using the extraction procedure as it was previously described. For the determination of the extraction isotherm and kinetic curves, both phases were mixed at $\mathrm{pH} 4$ and temperature of $25^{\circ} \mathrm{C}$, using $0.3 \mathrm{M}$ Cyanex 272 as organic phase. The experiments were conducted at different $\mathrm{A} / \mathrm{O}$ ratios varying between 0.2 and 6.5 in order to calculate the equilibrium isotherm. In the case of the kinetic studies, an $\mathrm{A} / \mathrm{O}$ ratio of 1.0 was fixed and solution samples were taken at 0.5, 1.0, 3.0, 5.0, 10.0, and $15.0 \mathrm{~min}$ for assay. The kinetic, equilibrium, and stripping tests were repeated with samples of the real leaching liquor taken from the bioleaching pilot plant.

After the phase separation, the metal content in the aqueous phase was analyzed by flame atomic absorption spectrophotometer, Perkin Elmer 3300. The pH measurements were carried out potentiometrically using a WTW $\mathrm{pH}$ meter, Inolab level.

\section{Analysis of the Extraction Conditions}

The efficiency of the liquid-liquid extraction process may depend on different variables (factors) and within this scope equilibrium $\mathrm{pH}$ (A), extractant concentration (B), $\mathrm{A} / \mathrm{O}$ ratio $(\mathrm{C})$, and temperature $(\mathrm{D})$ were selected for 
further evaluation. Aiming to analyze the synergetic effect of these four factors on a response, the design of experiments (DOE) methodology was applied $(31,32)$ followed by multiple linear regression (MLR) algorithms. In particular, a full factorial design of experiments was used to study the effect of those four factors, each one at two levels. Thus, the number of experiments in a complete trial was of $16\left(=2^{4}\right)$. The selected response variables, $\mathrm{Y}$, were the extraction yield of zinc, $\mathrm{Y}_{\mathrm{Zn}}(\%)$, the extraction yield of manganese, $\mathrm{Y}_{\mathrm{Mn}}(\%)$, and the separation factor, $\beta$, defined as:

$$
\begin{gathered}
Y_{Z n}(\%)=\frac{C_{Z n, \text { initial }}^{a q}-C_{Z n, e q}^{a q}}{C_{Z n, \text { initial }}^{a q}} \\
Y_{M n}(\%)=\frac{C_{M n, \text { initial }}^{a q}-C_{M n, e q}^{a q}}{C_{M n, \text { initial }}^{a q}} \\
\beta=\frac{D_{Z n}}{D_{M n}}=\frac{C_{Z n, e q}^{\text {org }} / C_{Z n, e q}^{a q}}{C_{M n, e q}^{\text {org }} / C_{M n, e q}^{a q}}
\end{gathered}
$$

where $C_{M \text {.initial }}^{a q}$ is the initial concentration of metal M ( $\mathrm{Zn}(\mathrm{II})$ or $\mathrm{Mn}(\mathrm{II}))$ in the aqueous phase, $C_{M, e q}^{a q}$ is the equilibrium concentration of metal $\mathrm{M}$ in the aqueous phase, and $C_{M, e q}^{o r g}$ is the equilibrium concentration of metal $\mathrm{M}$ in the organic phase.

The levels studied for each factor (A-D) are indicated in Table 2. Besides the experiments established through the full factorial, a center-point replicated run was also carried out in order to evaluate if the relationship between the factors and response variable is rather curve-linear and to estimate the error variance. A factorial design matrix was created and the experiments were carried out under different conditions to investigate the extraction process. The design and the statistical analysis of the experimental data were carried with the software STATISTICA, release 7, and in this case 15 effects $\left(2^{4}-1\right)$ may be determined. The codified linear regression model that include 2-way and 3-way interactions for each response variable $\left(\mathrm{Y}=\mathrm{Y}_{\mathrm{Zn}}\right.$,

TABLE 2

Extraction parameters and factor levels

\begin{tabular}{lccc}
\hline & \multicolumn{3}{c}{ Level } \\
\cline { 2 - 4 } Factor & Low $(-1)$ & Central $(0)$ & High $(+1)$ \\
\hline A-Equilibrium pH & 2.5 & 3.5 & 4.5 \\
B-Extractant & 0.05 & 0.275 & 0.50 \\
$\quad$ concentration $(\mathrm{M})$ & & & \\
C-A/O ratio & 0.5 & 1.0 & 1.5 \\
D-Temperature $\left({ }^{\circ} \mathrm{C}\right)$ & 25 & 37.5 & 50 \\
\hline
\end{tabular}

$\mathrm{Y}_{\mathrm{Mn}}$ and $\beta$ ) was used:

$$
\begin{aligned}
Y= & \beta_{0}+\sum_{i=1}^{4} \beta_{i} x_{i}+\sum_{i<j}^{4} \sum_{j=1}^{4} \beta_{i j} x_{i} x_{j} \\
& +\sum_{k<i}^{4} \sum_{i<j}^{4} \sum_{j=1}^{4} \beta_{i j k} x_{i} x_{j} x_{k}+\varepsilon
\end{aligned}
$$

where $\varepsilon$ is a random error component (31), the values of $\beta_{\mathrm{i}}$ account for the main effects of the factors $\mathrm{x}_{\mathrm{i}}, \beta_{\mathrm{ij}}$, and $\beta_{\mathrm{ijk}}$ are the second and third order interaction terms respectively, and the independent term $\beta_{0}$ represents the response at zero level of every factor $\left(x_{i}=0\right)$, that correspond to the response at the center of the design. Sometimes $\beta_{0}$ is referred as the global mean due to the fact that it corresponds just to the average of the runs (33). The variables $x_{i}$ are defined on a coded scale from -1 to 1 , which are associated to the low and high levels of A, B, C, and D factors, calculated as:

$$
\begin{aligned}
& x_{1}=\frac{A-3.5}{1} ; \quad x_{2}=\frac{B-0.275}{0.225} ; \quad x_{3}=\frac{C-1}{0.5} ; \\
& x_{4}=\frac{D-37.5}{12.5}
\end{aligned}
$$

where $\mathrm{A}, \mathrm{B}, \mathrm{C}$, and $\mathrm{D}$ are the operating values indicated in Table 2.

\section{RESULTS AND DISCUSSION}

\section{Selection of Extractants and Stripping Data}

The effect of equilibrium $\mathrm{pH}$ in range 1.0-5.0 on the extraction percentages of zinc and manganese by the extractants tested (Cyanex 272 and DEHPA) is shown in Fig. 1. The overall reaction in the extraction of divalent metals by cationic extractants can be described as follows (14):

$$
M_{(a q)}^{2+}+n(R H)_{p(o r g)} \Leftrightarrow M R_{n p} H_{n p-2(o r g)}+2 H_{(a q)}^{+}
$$

where $\mathrm{M}^{2+}$ represents metal ion, $(\mathrm{RH})_{\mathrm{p}}$ is the molecule of the extractant, $\mathrm{H}^{+}$is the hydrogen ion, and the subscripts (aq) and (org) refer to aqueous and organic phases, respectively. The equilibrium constant is given by the following equation:

$$
K_{e q}=\frac{\left[M R_{n p} H_{n p-2}\right]_{(o r g)}\left[H^{+}\right]_{(a q)}^{2}}{\left[M^{2+}\right]_{(a q)}\left[(R H)_{p}\right]_{(o r g)}^{n}}
$$

As shown in Eq. (7), the $\mathrm{pH}$ of the aqueous phase affects the reversible reaction of complexation-decomplexation. For Cyanex 272, Fig. 1a, almost $100 \%$ extraction of $\mathrm{Zn}$ (II) was observed in the $\mathrm{pH}$ range of 4.0 to 5.0 , whereas the extraction of $\mathrm{Mn}(\mathrm{II})$ varied from 22 to $87 \%$. In the case 


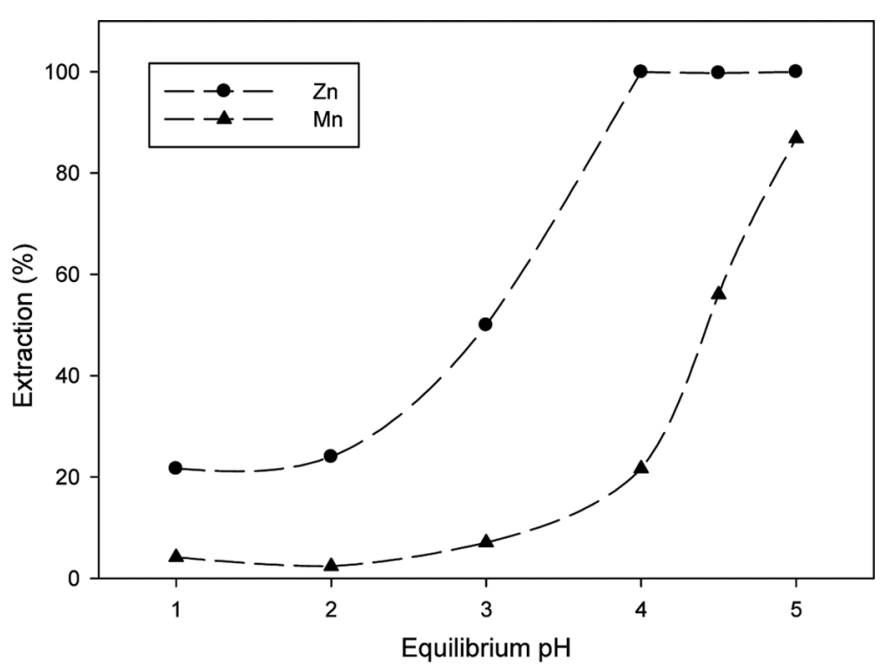

(a)

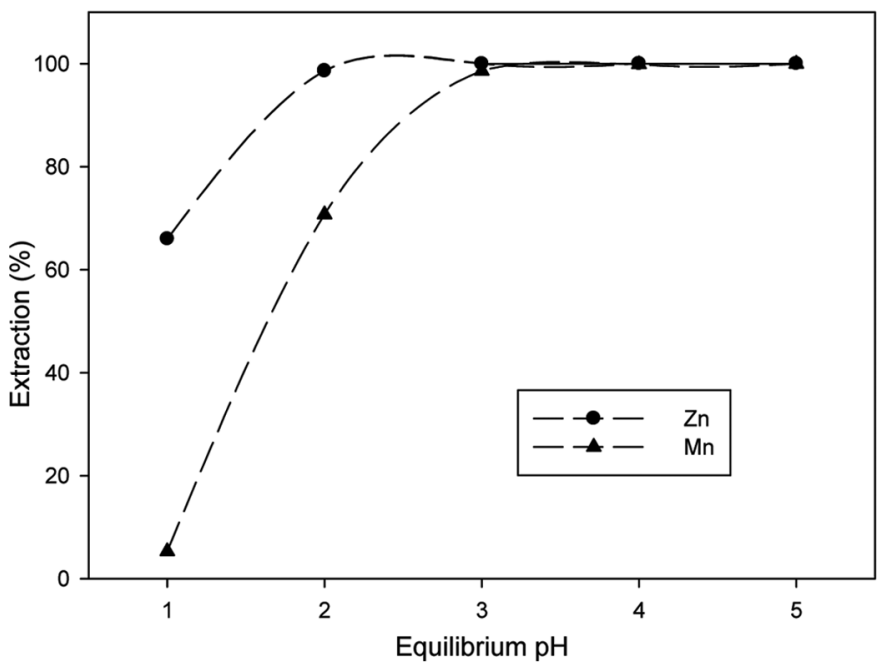

(b)

FIG. 1. Extraction efficiency (in percentage) of $\mathrm{Zn}$ (II) and $\mathrm{Mn}(\mathrm{II})$ as a function of equilibrium $\mathrm{pH}$ for the extractants in kerosene (a) Cyanex 272; (b) DEHPA.

of DEHPA, Fig. 1b, both metals are almost completely extracted from the aqueous phase for $\mathrm{pH}$ values higher than 3.0. In the $\mathrm{pH}$ range 1.0-3.0, the extraction percentages of $\mathrm{Zn}(\mathrm{II})$ and $\mathrm{Mn}(\mathrm{II})$ varied from 66 to $\approx 100 \%$ and 5.1 to $98.6 \%$, respectively. Regarding selectivity, Cyanex 272 is more efficient for the separation of zinc and manganese due to the distance between the extraction curves of $\mathrm{Zn}(\mathrm{II})$ and $\mathrm{Mn}(\mathrm{II})$. For this extractant, the $\Delta \mathrm{pH}_{1 / 2}$ (defined as variation of the $\mathrm{pH}$ in which $50 \%$ of metal in solution is extracted): $\Delta \mathrm{pH}_{1 / 2}=\mathrm{pH}_{1 / 2, \mathrm{Mn}}-\mathrm{pH}_{1 / 2, \mathrm{Zn}}=4.4-3.0$ is 1.4, indicating thus a reasonable level separation for the metal ions.

The separation factor, $\beta$ was calculated according to Eq. (3), and plotted against pH in Fig. 2. It can be seen that for DEHPA the factor $\beta$ is slightly dependent on $\mathrm{pH}$. The

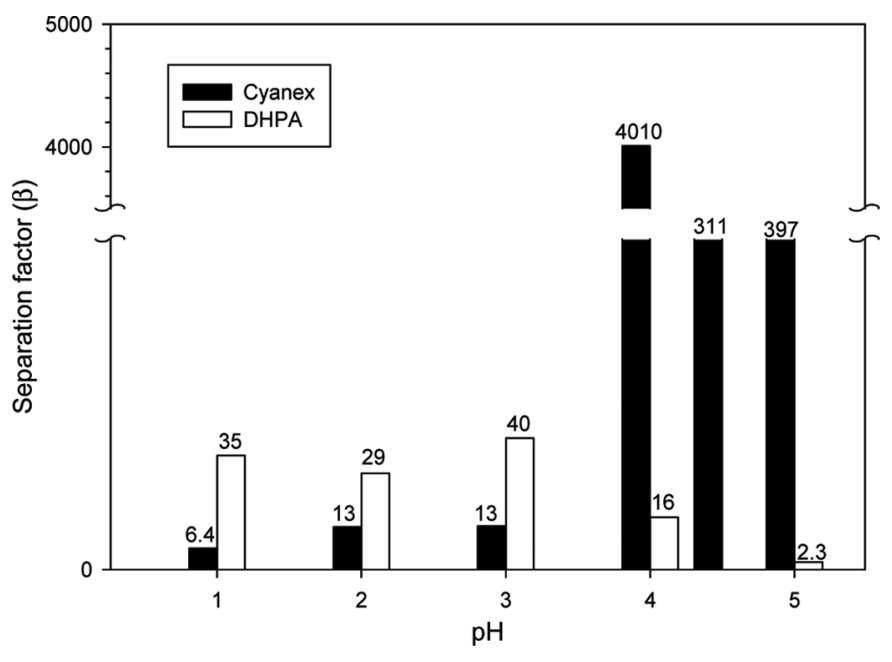

FIG. 2. Separation factor $\left(\beta=\mathrm{D}_{\mathrm{Zn}} / \mathrm{D}_{\mathrm{Mn}}\right)$ against equilibrium $\mathrm{pH}$ for extractants Cyanex and DEHPA.

highest $\beta$ was achieved with Cyanex 272 at $\mathrm{pH} 4$, reaching a value of 4010 . Thus, the extractant agent Cyanex 272 was chosen for separating $\mathrm{Zn}$ (II) and $\mathrm{Mn}$ (II) from leach solutions in the scope of this work.

After the extraction, the organic phase was mixed with $1 \mathrm{M} \mathrm{H}_{2} \mathrm{SO}_{4}$ solution in a separatory funnel to separate $\mathrm{Zn}$ (II) from the metal complex formed with Cyanex 272 in the organic phase. The resultant $\mathrm{ZnSO}_{4}$ solution is the final product, where $\mathrm{Zn}(\mathrm{II})$ can be precipitated or recrystallized and the organic solvent can be reutilized. The stripping efficiencies obtained at different equilibrium $\mathrm{pH}$ are summarized in Table 3. For the solution at equilibrium $\mathrm{pH}$ of 4.0, a higher separation factor was reached, and in this case about $90 \%$ of zinc and $8 \%$ of manganese were transferred into the aqueous phase, suggesting thus that sulphuric acid at moderate concentrations can be used efficiently for recovering $\mathrm{Zn}(\mathrm{II})$.

\section{Effect of the Extraction Conditions in Response Variables Using Full-Factorial Design}

Four variables were identified as potentially important with respect to the efficiency of the extraction of $\mathrm{Zn}$ $\left(=\mathrm{Y}_{\mathrm{Zn}}\right)$ and $\mathrm{Mn}\left(=\mathrm{Y}_{\mathrm{Mn}}\right)$, and also for the separation factor $(\beta)$ by using Cyanex 272: equilibrium $\mathrm{pH}(\mathrm{A})$,

TABLE 3

Stripping efficiencies of metals at different equilibrium $\mathrm{pH}$ for Cyanex 272

Stripping efficiencies (\%)

\begin{tabular}{lcrrrrr} 
& pH 1 & pH 2 & pH 3 & pH 4 & pH 4.5 & pH 5 \\
\hline $\mathrm{Zn}(\mathrm{II})$ & 6.7 & 16.4 & 41.0 & 89.7 & 81.1 & 84.4 \\
$\mathrm{Mn}(\mathrm{II})$ & 2.3 & 2.0 & 2.7 & 7.7 & 42.8 & 73.9 \\
\hline
\end{tabular}


TABLE 4

Full-factorial $\left(2^{4}\right)$ matrix with one replication of the central point

\begin{tabular}{lcccccccc}
\hline & \multicolumn{4}{c}{ Factors } & & \multicolumn{3}{c}{ Response variables } \\
\cline { 2 - 5 } \cline { 8 - 9 } Experiment & $\mathrm{A}$ & $\mathrm{B}$ & $\mathrm{C}$ & $\mathrm{D}$ & & $\mathrm{Y}_{\text {Zn }}(\%)$ & $\mathrm{Y}_{\text {Mn }}(\%)$ & $\beta$ \\
\hline E1 & +1 & +1 & +1 & +1 & & 99.94 & 66.73 & 818.7 \\
E2 & +1 & -1 & +1 & +1 & & 62.59 & 16.38 & 8.538 \\
E3 & +1 & +1 & -1 & +1 & & 32.10 & 21.39 & 1.738 \\
E4 & +1 & +1 & +1 & -1 & & 99.83 & 98.85 & 6.723 \\
E5 & +1 & +1 & -1 & -1 & & 64.02 & 47.51 & 1.966 \\
E6 & +1 & -1 & -1 & +1 & & 59.60 & 43.82 & 1.891 \\
E7 & -1 & -1 & +1 & +1 & & 78.62 & 36.09 & 6.511 \\
E8 & +1 & -1 & +1 & -1 & & 93.25 & 32.62 & 28.54 \\
E9 & -1 & +1 & -1 & +1 & & 32.29 & 31.72 & 1.027 \\
E10 & -1 & -1 & -1 & -1 & & 30.50 & 24.36 & 1.362 \\
E11 & -1 & +1 & +1 & +1 & & 99.93 & 52.59 & 1238 \\
E12 & +1 & -1 & -1 & -1 & & 35.55 & 17.79 & 2.549 \\
E13 & -1 & +1 & -1 & -1 & & 62.21 & 39.94 & 2.475 \\
E14 & -1 & -1 & +1 & -1 & & 98.97 & 46.80 & 108.8 \\
E15 & -1 & +1 & +1 & -1 & & 100.0 & 100.0 & 1.000 \\
E16 & -1 & -1 & -1 & +1 & & 16.81 & 24.75 & 0.615 \\
E17 & 0 & 0 & 0 & 0 & 93.00 & 31.78 & 28.52 \\
E18 & 0 & 0 & 0 & 0 & 94.08 & 25.92 & 45.45 \\
\hline
\end{tabular}

extractant concentration (B), A/O ratio (C), and temperature (D). In this context, it is well known that factorial designs are best strategies than one-factor-at-a-time methodology (31-33). Indeed, in the case of interactions between factors, factorial designs may avoid misleading conclusions. As indicated in Table 2, in our study a two level factorial design $\left(2^{\mathrm{k}}\right)$ was used, for four independent factors tested. Table 4 summarizes the matrix describing the eighteen experiments (E1-E18), which correspond to a randomly full factorial trial experiment at two levels (E1-E16) plus a replicate at a central point (E17-E18). In fact, the only way for obtaining the error analysis in a two-level factorial design without neglecting model terms is by duplicating experiments, for example at the center of the design, which correspond to all factor levels set equal zero (33). In this case, the variance of each coefficient may be calculated. The input results of the factorial design (Table 4) were analyzed statistically using analysis of variance (ANOVA) with the STATISTICA.7 software, which led to the effects and coefficients indicated in Table 5. These results were obtained by selecting a global model equal to the one indicated in Eq. (4), that includes 2-way and 3-way interactions and choosing the possibility

TABLE 5

Effects and significance in each of response variables $\left(\mathrm{Y}_{\mathrm{Zn}}, \mathrm{Y}_{\mathrm{Mn}}, \beta\right)$

\begin{tabular}{|c|c|c|c|c|c|c|c|c|c|c|c|c|}
\hline & \multicolumn{4}{|c|}{$Y_{\mathrm{Zn}}(\%)$} & \multicolumn{4}{|c|}{$Y_{M n}(\%)$} & \multicolumn{4}{|c|}{$\beta$} \\
\hline & Effect & $\mathrm{p}$ & Coeff & SE & Effect & $\mathrm{p}$ & Coeff & SE & Effect & $\mathrm{p}$ & Coeff & SE \\
\hline Mean & 66.64 & 0.001 & 66.64 & 2.22 & 43.83 & 0.004 & 43.83 & 2.94 & 139.40 & 0.025 & 139.4 & 22.6 \\
\hline Curvature & 53.81 & 0.056 & 26.90 & 6.67 & -29.97 & 0.231 & -14.98 & 8.81 & -204.83 & 0.270 & -102.4 & 67.7 \\
\hline$x_{1}$ & 14.30 & 0.085 & 7.15 & 2.22 & 27.02 & 0.044 & 13.51 & 2.94 & 239.12 & 0.034 & 119.6 & 22.6 \\
\hline$x_{2}$ & 50.00 & 0.008 & 25.00 & 2.22 & 24.85 & 0.052 & 12.42 & 2.94 & 275.40 & 0.026 & 137.7 & 22.6 \\
\hline$x_{3}$ & -12.81 & 0.102 & -6.40 & 2.22 & -14.30 & 0.135 & -7.15 & 2.94 & 240.46 & 0.033 & 120.2 & 22.6 \\
\hline$x_{4}$ & 3.44 & 0.520 & 1.72 & 2.22 & -1.40 & 0.834 & -0.70 & 2.94 & -61.15 & 0.308 & -30.6 & 22.6 \\
\hline$x_{1} x_{2}$ & 2.26 & 0.662 & 1.13 & 2.22 & 19.56 & 0.080 & 9.78 & 2.94 & 238.92 & 0.034 & 119.5 & 22.6 \\
\hline$x_{1} x_{3}$ & -2.64 & 0.613 & -1.32 & 2.22 & -14.17 & 0.137 & -7.08 & 2.94 & 271.38 & 0.027 & 135.7 & 22.6 \\
\hline$x_{1} x_{4}$ & -3.08 & 0.561 & -1.54 & 2.22 & 3.95 & 0.570 & 1.98 & 2.94 & -42.22 & 0.448 & -21.1 & 22.6 \\
\hline$x_{2} x_{3}$ & 0.06 & 0.990 & 0.03 & 2.22 & -12.32 & 0.171 & -6.16 & 2.94 & 241.23 & 0.033 & 120.6 & 22.6 \\
\hline$x_{2} x_{4}$ & -8.92 & 0.183 & -4.46 & 2.22 & -3.83 & 0.581 & -1.92 & 2.94 & -61.81 & 0.304 & -30.9 & 22.6 \\
\hline$x_{3} x_{4}$ & 3.20 & 0.547 & 1.60 & 2.22 & 2.19 & 0.745 & 1.09 & 2.94 & -42.69 & 0.444 & -21.3 & 22.6 \\
\hline$x_{1} x_{2} x_{3}$ & 15.40 & 0.074 & 7.70 & 2.22 & 1.02 & 0.878 & 0.51 & 2.94 & 271.44 & 0.027 & 135.7 & 22.6 \\
\hline$x_{1} x_{2} x_{4}$ & 8.48 & 0.197 & 4.24 & 2.22 & 7.77 & 0.317 & 3.88 & 2.94 & -41.65 & 0.454 & -20.8 & 22.6 \\
\hline$x_{1} x_{3} x_{4}$ & -3.65 & 0.498 & -1.83 & 2.22 & -2.84 & 0.677 & -1.42 & 2.94 & -63.28 & 0.296 & -31.6 & 22.6 \\
\hline$x_{2} x_{3} x_{4}$ & -5.73 & 0.326 & -2.87 & 2.22 & 0.25 & 0.970 & 0.13 & 2.94 & -43.02 & 0.441 & -21.5 & 22.6 \\
\hline Global Model & \multicolumn{4}{|c|}{ Eq. (4) } & \multicolumn{4}{|c|}{ Eq. (4) } & \multicolumn{4}{|c|}{ Eq. (4) } \\
\hline $\mathrm{MS}_{\text {Residual }}$ & \multicolumn{4}{|c|}{79.17} & \multicolumn{4}{|c|}{138.1} & \multicolumn{4}{|c|}{8152} \\
\hline $\mathrm{R}^{2}$ Pred vs Obs & \multicolumn{4}{|c|}{0.989} & \multicolumn{4}{|c|}{0.973} & \multicolumn{4}{|c|}{0.992} \\
\hline Simplest model & \multicolumn{4}{|c|}{$\begin{array}{c}\text { Eq. (8) } \\
5179\end{array}$} & \multicolumn{4}{|c|}{ Eq. (9) } & \multicolumn{4}{|c|}{ Eq. (10) } \\
\hline $\mathrm{MS}_{\text {Residual }}$ & \multirow{2}{*}{\multicolumn{4}{|c|}{$\begin{array}{l}51.79 \\
0.965\end{array}$}} & \multirow{2}{*}{\multicolumn{4}{|c|}{$\begin{array}{l}51.21 \\
0.955\end{array}$}} & & 95 & & \\
\hline $\mathrm{R}^{2}$ Pred vs Obs & & & & & & & & & \multicolumn{4}{|c|}{0.960} \\
\hline
\end{tabular}

${ }^{*}$ SE-Standard error. 
of curvature check. The p-values showed in Table 5 correspond to the statistical significance of the effects and represent a decreasing index of the reliability of an effect being significant. Thus, the p-values of less than 0.05 indicate that the coefficients of the models equations are significant. $\mathrm{MS}_{\text {Residual }}$ values are the mean square of the residuals, and $\mathrm{R}^{2}$ is a measure of the reduction in the total variation of the dependent variables due to the multiple independent variables. For example, $\mathrm{R}^{2}=0.989$ means that a model equation can account for more that $98.9 \%$ of the variability.

From the results indicated in Table 5, it may be concluded with $95 \%$ of confidence that the most significant main effect on $\mathrm{Y}_{\mathrm{Zn}}$ is the extractant concentration $\left(\mathrm{x}_{2}\right)$ and none of the interactions are statistically significant in this case. For the case of $\mathrm{Y}_{\mathrm{Mn}}$ the main effect is equilibrium $\mathrm{pH}\left(\mathrm{x}_{1}\right)$ and none of the interactions are particularly important. However, for $\beta$ besides equilibrium $\mathrm{pH}\left(\mathrm{x}_{1}\right)$, extractant concentration $\left(\mathrm{x}_{2}\right)$ and $\mathrm{A} / \mathrm{O}$ ratio $\left(\mathrm{x}_{3}\right)$ some interactions $\left(\mathrm{x}_{1} \mathrm{x}_{2}, \mathrm{x}_{1} \mathrm{x}_{3}, \mathrm{x}_{2} \mathrm{x}_{4}\right.$, and $\left.\mathrm{x}_{1} \mathrm{x}_{2} \mathrm{x}_{3}\right)$ have an important contribution to this variable. None of the response variables seem to be significantly dependent on the temperature $\left(\mathrm{x}_{4}\right)$. Although the curvatures were not statistically

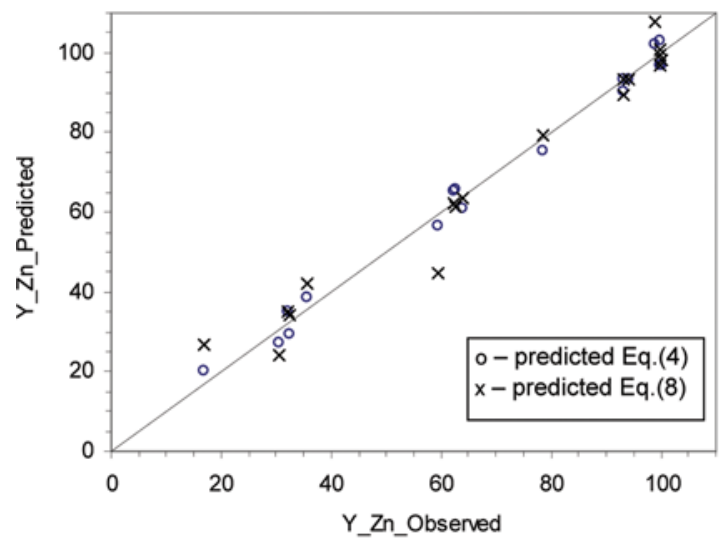

(a) significant $(p>0.05)$ for all the response variables, $Y_{Z n}$, $\mathrm{Y}_{\mathrm{Mn}}$, and $\beta$, the inclusion of this effect leads to higher $\mathrm{R}^{2}$ and lower $\mathrm{MS}_{\text {residuals. }}$

The ability of a multiple linear model equation to describe the real behavior of the response variables may be evaluated by fitting the observed against the predicted values, as indicated in Figs. 3a-c. The solid diagonal lines $(y=x)$ represent the ideal cases where the predicted and the observed values are equal. In addition, in each figure are shown both the points predicted with the global model, Eq. (4) (symbol: o), and with simpler models (symbol: x), that were calculated with Eqs. (8), (9), and (10) for $\mathrm{Y}_{\mathrm{Zn}}$, $\mathrm{Y}_{\mathrm{Mn}}$, and $\beta$, respectively. In the case of the global model, the regression coefficients used are listed in Table 5. In both cases the slightly deviated points from the diagonal line, means that the prediction values are in agreement with the experimental ones, and if necessary the simplest models, Eqs. (8) to (10), may be used instead of the global one represented by Eq. (4).

$$
\begin{aligned}
Y_{Z n}(\%)= & 66.64+7.15 x_{1}+25.00 x_{2}-6.40 x_{3}-4.76 x_{2} x_{4} \\
& +7.70 x_{1} x_{2} x_{3}+4.24 x_{1} x_{2} x_{4}
\end{aligned}
$$

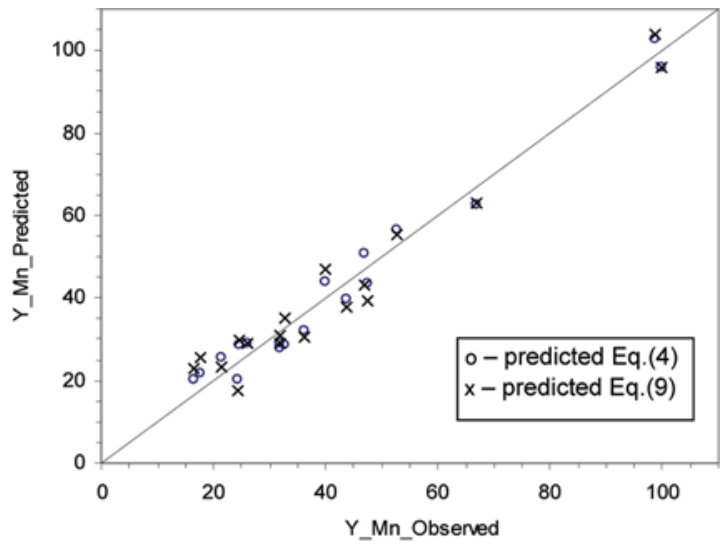

(b)

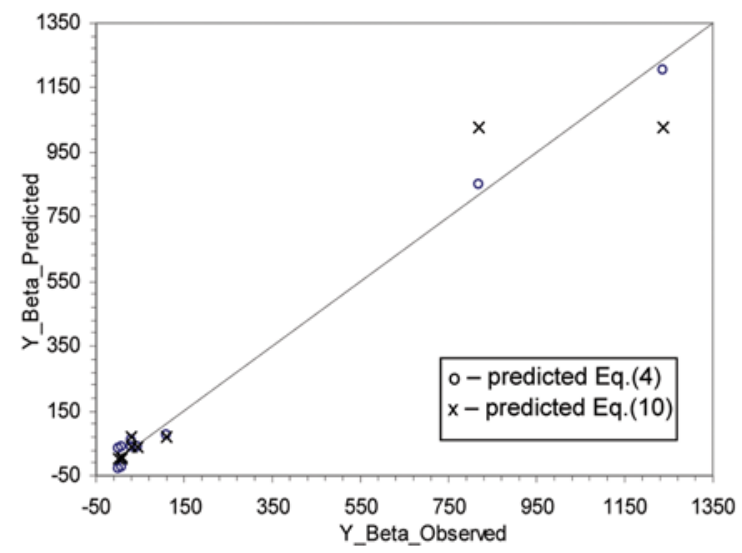

(c)

FIG. 3. Predicted versus observed values of (a) $\mathrm{Y}_{\mathrm{Zn}}$; (b) $\mathrm{Y}_{\mathrm{Mn}}$; (c) $\mathrm{Y}_{\beta}$. 


$$
Y_{M n}(\%)=43.83+13.51 x_{1}+12.40 x_{2}-7.15 x_{3}+9.78 x_{1} x_{2}
$$

$$
-7.08 x_{1} x_{3}-6.16 x_{2} x_{3}+3.88 x_{1} x_{2} x_{4}
$$

$$
\begin{aligned}
Y_{\beta}= & 139.4+119.6 x_{1}+137.7 x_{2}+120.2 x_{3}-30.57 x_{4} \\
& +119.5 x_{1} x_{2}+135.7 x_{1} x_{3}+120.6 x_{2} x_{3} \\
& +135.7 x_{1} x_{2} x_{3}
\end{aligned}
$$

It is important to note that for simulating the center points, the values of curvature indicated in Table 5 should be added to the model. On the other hand, the p-value associated with the curvature shown in Table 5, mainly for $\mathrm{Y}_{\mathrm{Zn}}$ is close to 0.05 , indicates that nonlinearity may be included in the model for predicting a response of this process. These findings may suggest that further studies of the process of extraction should be performed in the future by using another method capable of describing the nature of this curvature. A possible strategy is to use a central composite design (34), Box-Behnken design (35), three-level factorial or Doehlert designs (36) instead of two-level factorial designs, and fit the results to the codified quadratic regression model, as for example:

$$
Y=\beta_{0}+\sum_{i=1}^{4} \beta_{i} x_{i}+\sum_{i=1}^{4} \beta_{i i} x_{i}^{2}+\sum_{i<j}^{4} \sum_{j=1}^{4} \beta_{i j} x_{i} x_{j}+\varepsilon
$$

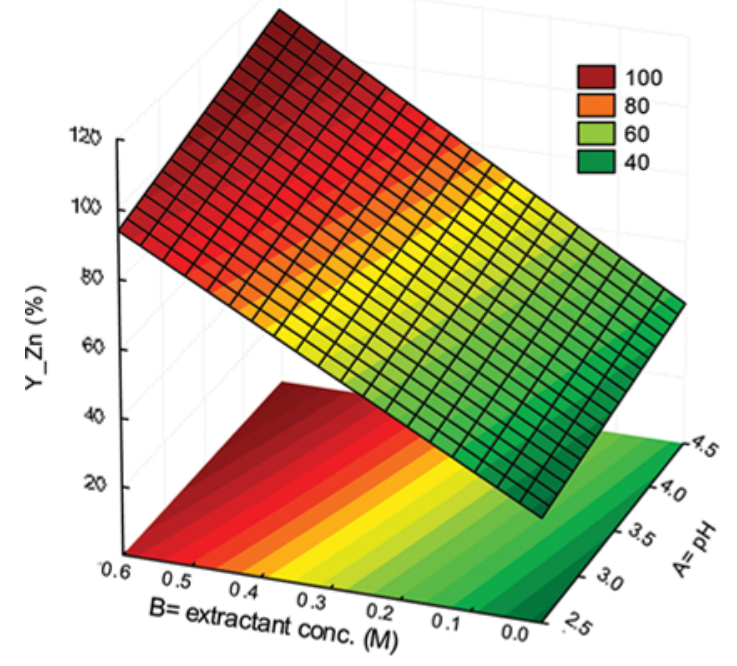

(a)

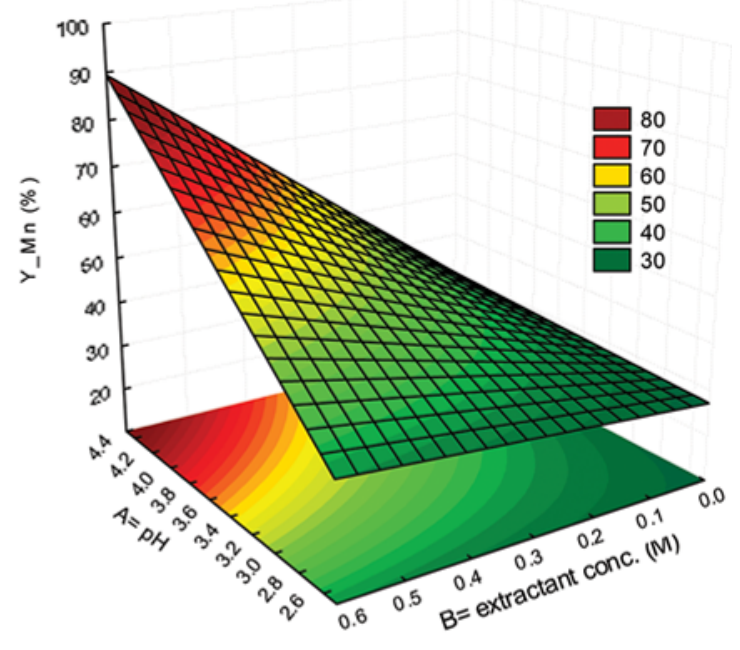

(b)

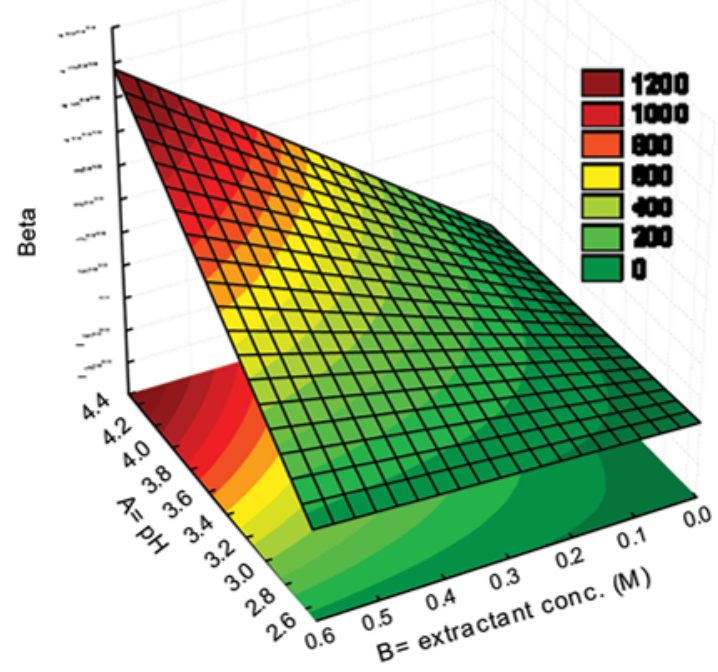

(c)

FIG. 4. Response surfaces of (a) $\mathrm{Y}_{\mathrm{Zn}}$; (b) $\mathrm{Y}_{\mathrm{Mn}}$; (c) $\beta$ as a function of factors: A-equilibrium $\mathrm{pH}$ and B-extractant concentration. 
where the meaning of the variables in Eq. (11) are the same as described for Eq. (4). This model may be very useful in the scope of a response surface methodology (RSM), which is a collection of statistical techniques for optimizing responses of dependent variables that may be dependent on several independent variables (31). These types of models are particularly useful to determine critical (optimum) points such as maximum, minimum, or saddle.

Nevertheless, with the surfaces generated by the regression model of Eq. (4) it is possible to determine the directions in which the design must be improved in order to determine the optimal conditions of extraction. In fact, even in this case, the visualization of the predicted model equation can be obtained by RSM. In our study, three out of several possible response surfaces were selected as a function of $\mathrm{pH}$ (factor $\mathrm{A}$ ) and extractant concentration (factor B): Fig. $4 a$ is related to $\mathrm{Y}_{\mathrm{Zn}}$, Fig. $4 \mathrm{~b}$ to $\mathrm{Y}_{\mathrm{Mn}}$, and Fig. $4 \mathrm{c}$ to $\beta$. Considering that the main objective in terms of the extraction conditions is to separate $\mathrm{Zn}(\mathrm{II})$ and $\mathrm{Mn}(\mathrm{II})$, this is attained by maximizing the yield of $\mathrm{Zn}$ (II) and at the same time minimizing the yield of Mn(II). In other words, the extraction conditions should be selected for achieving a maximum separation factor $(\beta)$. From the analysis of these figures, it was possible to conclude that the target region to be further explored in order to maximize the separation factor, $\beta$, should be: equilibrium $\mathrm{pH}$ higher than 3.5 and the extractant concentration higher than $0.4 \mathrm{M}$.

\section{Extraction Isotherm}

The extraction isotherms for the $\mathrm{Zn}$ (II) using $0.3 \mathrm{M}$ Cyanex 272 at $\mathrm{pH} 4$ and $25^{\circ} \mathrm{C}$ are plotted in Figs. 5a and $5 \mathrm{~b}$, for synthetic and real liquor, respectively. To construct the isotherms which are plots of the concentration of the metal in organic phase versus the concentration of the metal in the aqueous phase, zinc concentrations in both aqueous phases were obtained with a series of experiments at different $\mathrm{A} / \mathrm{O}$ ratios. The McCabe-Thiele construction was used to calculate the optimal number of extraction steps in both systems (synthetic and real leaching liquor) where the operation line corresponds to $\mathrm{A} / \mathrm{O}$ ratio of 1 . According to this method, one step is enough for the extraction of the zinc from the synthetic leaching solution, yielding an aqueous phase (raffinate) containing a few $\mathrm{mg} / \mathrm{L}$ of this metallic ion (Fig. 5a). However, for the real leaching liquor, it was found that two steps are required for the total extraction of the zinc (Fig. 5b). Thus, for this case, an incomplete extraction of zinc is obtained in one single stage probably because of the interference of contaminant metal ions, mainly iron ions, in the leaching solution (see Table 1). For instance, the experimental results showed that after a single contact at $\mathrm{A} / \mathrm{O}$ ratio of $1.0,85.6 \%$ of zinc and $1.2 \%$ of manganese were extracted

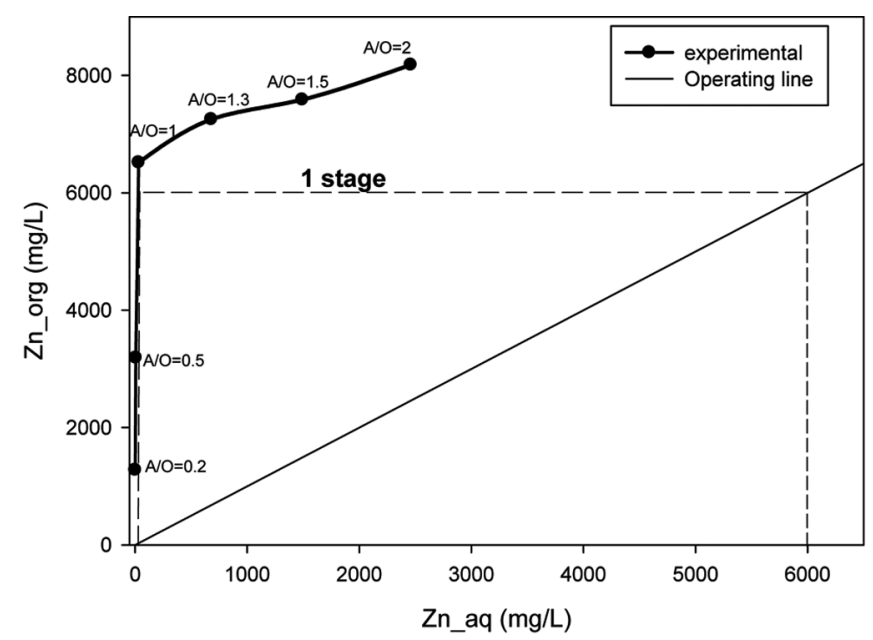

(a)

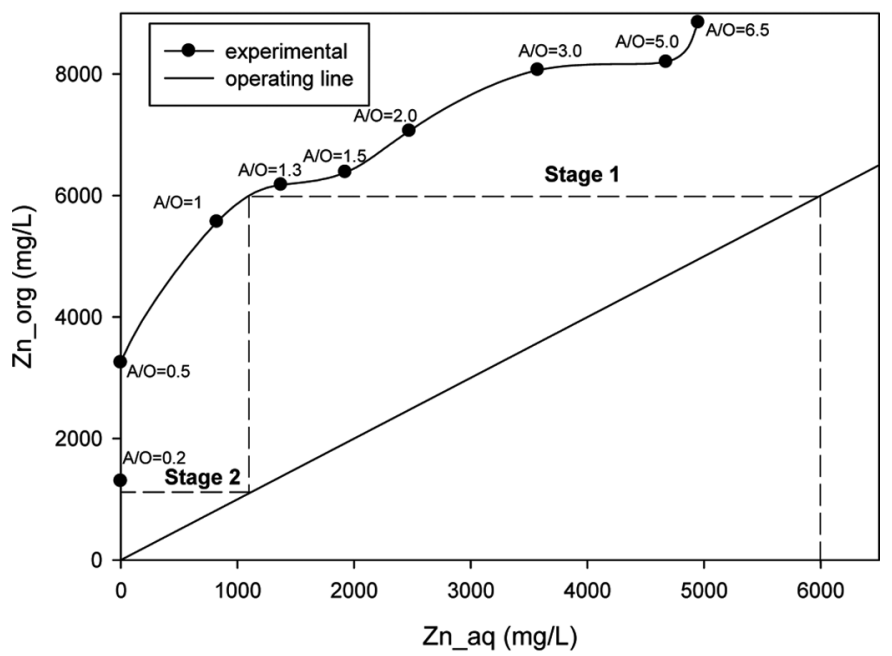

(b)

FIG. 5. Equilibrium isotherm and McCabe-Thiele construction for the extraction of Zn(II) with Cyanex 272: (a) synthetic effluent; (b) real leaching liquor.

from the real liquor while the extraction of zinc from synthetic solution was found to be $99.5 \%$.

\section{Metal Extraction Kinetics}

The extraction kinetics of zinc and manganese at $\mathrm{pH} 4$ and $25^{\circ} \mathrm{C}$ are shown in Fig. 6a for the synthetic leach solution and in Fig. $6 \mathrm{~b}$ for the leaching liquor from the pilot plant. In Fig. 6 (a), the kinetic behavior for $\mathrm{Zn}(\mathrm{II})$ is characterized by a very fast extraction phase, where nearly $64 \%$ of zinc was extracted in $1 \mathrm{~min}$, followed by a period of a slow extraction rate in which approximately $100 \%$ of the metal was extracted within $15 \mathrm{~min}$. About $83 \%$ of the ultimate extraction percentage of manganese $(21 \%)$ is achieved in the first minute, indicating its very fast extraction kinetics. The kinetics for extracting the metals from the synthetic solution is faster than the one with the real 


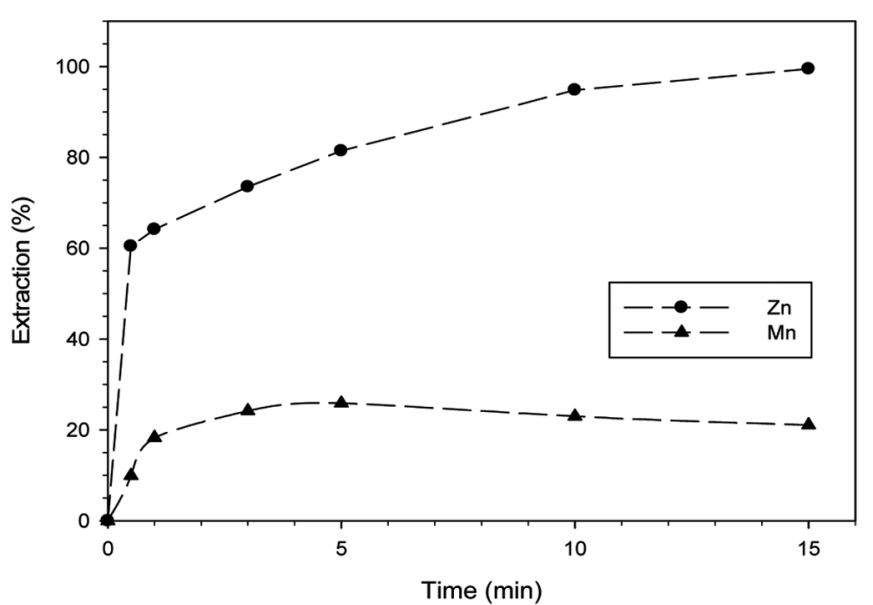

(a)

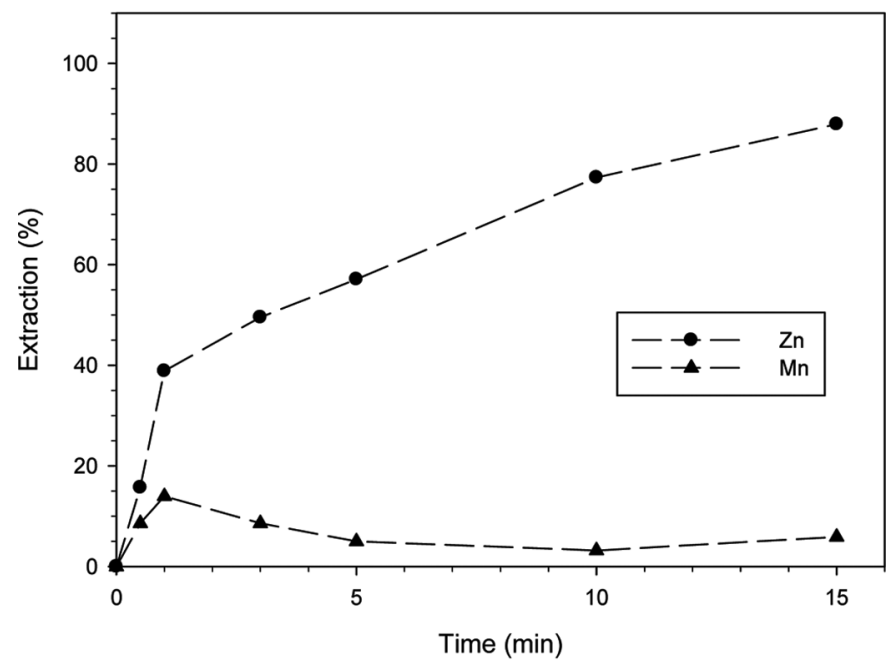

(b)

FIG. 6. Metal extraction kinetics with $0.3 \mathrm{M}$ Cyanex 272 at $\mathrm{pH}=4$ and $\mathrm{A} / \mathrm{O}=1$ : (a) synthetic effluent; (b) real leaching liquor.

leaching liquor, Fig. $6 \mathrm{~b}$, were the $39 \%$ of $\mathrm{Zn}(\mathrm{II})$ and $14 \%$ of $\mathrm{Mn}(\mathrm{II})$ were extracted in the first minute and $88 \%$ of $\mathrm{Zn}(\mathrm{II})$ and $6 \%$ of $\mathrm{Mn}(\mathrm{II})$ after $15 \mathrm{~min}$. It should be noted that in both systems, the manganese extraction increases during a short initial period, but then decreases, suggesting the crowding effect of zinc (37). As shown in Fig. 6b, this decrease was more marked in the case of the extraction of metals from the real liquor probably due to the coextraction of iron which is the main metal contaminant.

The comparison between extraction and stripping kinetics for the real leaching liquor is shown in Figs. 7a and $7 \mathrm{~b}$. As mentioned in the experimental part, zinc and manganese were stripped from loaded organic phase with $1 \mathrm{M} \mathrm{H}_{2} \mathrm{SO}_{4}$ at $\mathrm{pH} 4$ and $\mathrm{A} / \mathrm{O}$ equal to 1 . In 3 min about $50 \%$ of $\mathrm{Zn}$ (II) was extracted from aqueous phase using Cyanex 272. The zinc stripping efficiency achieved was $43 \%$ in $3 \mathrm{~min}$, indicating that the stripping kinetics is

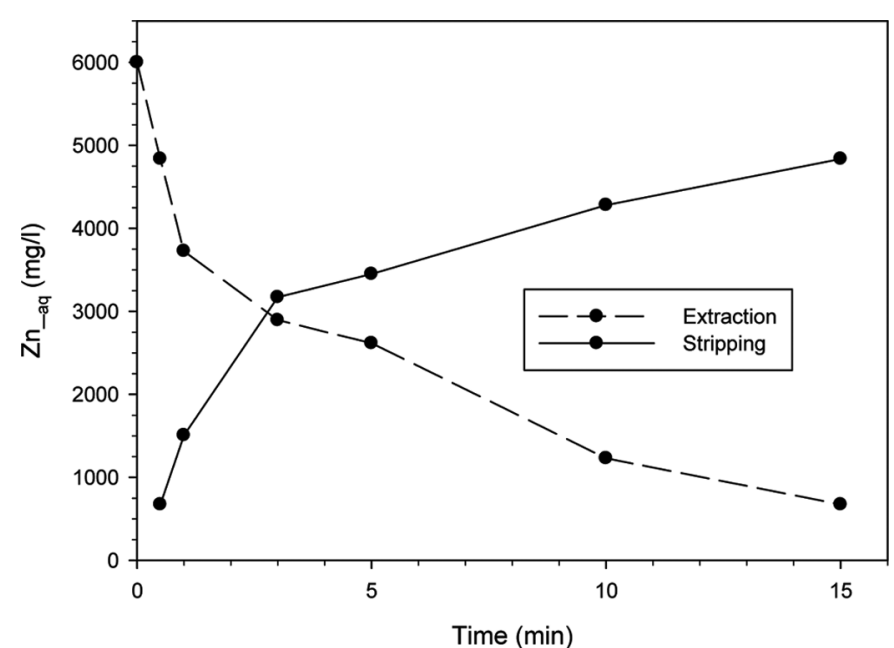

(a)

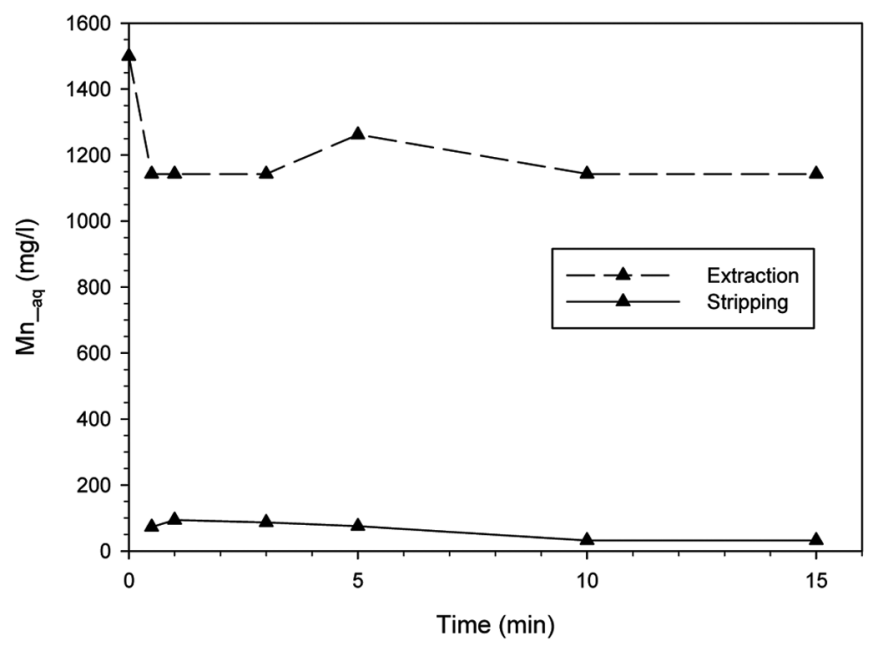

(b)

FIG. 7. Comparison between extraction and stripping kinetics for the real leaching liquor with $0.3 \mathrm{M}$ Cyanex 272 at $\mathrm{pH}=4$ and $\mathrm{A} / \mathrm{O}=1$ for (a) zinc; (b) manganese.

slower. After $15 \mathrm{~min}$ the $\mathrm{Zn}(\mathrm{II})$ concentration in the aqueous phase increased from 674 to $4837 \mathrm{mg} / \mathrm{L}$ corresponding to a stripping efficiency of $71 \%$. It can be concluded that acid sulphuric can be effective for zinc stripping from Cyanex 272. Regarding Mn(II), low stripping concentrations were observed after $15 \mathrm{~min}$, Fig. $7 \mathrm{~b}$.

These findings show that Cyanex 272 enables the separation of zinc and manganese through the extraction process studied in this work that is fast and efficient. Moreover, the stripping phase can be an efficient process, involving also rapid kinetics.

\section{Process Flow Sheet}

With the aim of recovering zinc and manganese, and taking into account the results obtained in this study, a conceptual process flow sheet as shown in Fig. 8 using 


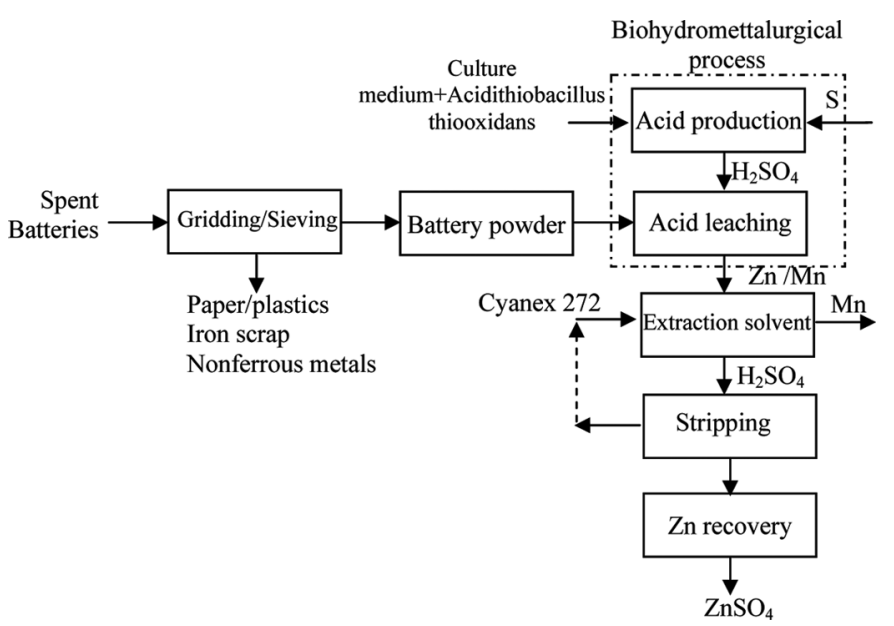

FIG. 8. A process flowsheet for the recovery of zinc and manganese from spent $\mathrm{Zn}-\mathrm{C}$ batteries.

the extraction system with Cyanex 272 as extractant agent can be developed. First, the waste (spent batteries) is treated by using mechanical operations in order to separate undesirable components such as paper, plastics, and nonferrous metals, as well as to reduce the particle sizes aiming at the improvement metal dissolution rates in the aqueous phase. Second, the battery powder is leached in a sulphuric acid and reducing compounds solution produced by Acidithiobacillus thiooxidans bacteria in a bioreactor. Therefore, the proposed strategy corresponds to a biohydrometallurgical process. Finally, zinc and manganese can be completely separated through an extraction system with Cyanex 272. Manganese is recovered in the aqueous phase. Regarding zinc, it is contained first in the organic phase (Cyanex 272) and then requires a stripping phase to regenerate the solvent and collect the metal as $\mathrm{ZnSO}_{4}$.

\section{CONCLUSIONS}

According to the results obtained in the experimental study of the solvent extraction of zinc and manganese from a mixed $\mathrm{ZnSO}_{4}$ and $\mathrm{MnSO}_{4}$ solution it can be concluded that Cyanex 272 diluted in kerosene is a better extractant and more selective to $\mathrm{Zn}(\mathrm{II})$ than DEHPA. The effect of extraction conditions (equilibrium $\mathrm{pH}$, extractant concentration, $\mathrm{A} / \mathrm{O}$ ratio, and temperature) in response variables (efficiency of the extraction of $\mathrm{Zn}(\mathrm{II}), \mathrm{Y}_{\mathrm{Zn}}$, efficiency of the extraction of $\mathrm{Mn}(\mathrm{II}), \mathrm{Y}_{\mathrm{Mn}}$, separation factor, $\beta$ ) were analyzed using a full-factorial design. From this analysis, it was concluded with $95 \%$ of confidence that the most significant main effect in $\mathrm{Y}_{\mathrm{Zn}}$ is the extractant concentration; in the case of $\mathrm{Y}_{\mathrm{Mn}}$ the main effect is the equilibrium $\mathrm{pH}$. However, for $\beta$ parameter besides equilibrium $\mathrm{pH}$, extractant concentration, and $\mathrm{A} / \mathrm{O}$ ratio, some second and third order interactions have an important contribution. None of the response variables seem to be notably dependent on the temperature. The design of experiments methodology allowed establishing a global codified linear regression model to the response variable as a function of the input factors. By considering only the significant effects, simplified equations were also obtained that can be used for predicting responses.

Considering Cyanex 272 concentration of $0.3 \mathrm{M}$, pH 4 and $\mathrm{A} / \mathrm{O}$ ratio equal to 1 , more than $95 \%$ of the total $\mathrm{Zn}$ (II) is extracted and less than the $20 \%$ of the manganese remains in the organic solution, obtaining at $25^{\circ} \mathrm{C}$ similar results as Salgado et al. (14) reached in their experiments at $50^{\circ} \mathrm{C}$, so a separation of both metals is feasible. After the extraction, the organic solution is stripped with $1 \mathrm{M}$ $\mathrm{H}_{2} \mathrm{SO}_{4}$, and in this step the extractant can be recycled and a solution containing $\mathrm{ZnSO}_{4}$ is obtained.

Experimental studies of the extraction isotherms and the application of the McCabe-Thiele construction showed that one extraction step is enough to attain high extraction of zinc for the synthetic solution. In the case of the leaching liquor, two steps are suggested for the total extraction of $\mathrm{Zn}$ (II) being that in the first step about $90 \%$ of $\mathrm{Zn}(\mathrm{II})$ is extracted. Extraction kinetics tests using a synthetic solution demonstrated that in 15 minutes almost all of the zinc is extracted while less than $20 \%$ of the manganese remains in the organic phase. Lower extraction percentages were achieved for both metals using the real leaching liquor system probably because of the presence of other metal ions, mainly iron.

As it was initially expected, $\mathrm{Zn}$ (II) can be extracted with Cyanex 272 in maximum two steps of $15 \mathrm{~min}$, at $25^{\circ} \mathrm{C}$, and low concentrations of extractant, that can then be recovered by a stripping process, so the costs of the process can be relatively low.

As an overall conclusion, it can be stated that solvent extraction route can be efficiently applied to the separation step of a biohydrometallurgical process in order to recover $\mathrm{Zn}$ (II) and $\mathrm{Mn}$ (II) from spent zinc-carbon and alkaline batteries.

\section{FUNDING}

Lorena Falco is a $\mathrm{PhD}$ student from the National University of La Plata, and has a scholarship from Comisión de Investigaciones Científicas de la Provincia de Buenos Aires. This research work was possible thanks to the ERASMUS-BAPE project, lot 18, and the University of Coimbra.

\section{REFERENCES}

1. Directive of the European Communities, Directive 2006/66/EC of The European Parliament and of The Council On Batteries and Accumulators and Spent Batteries and Accumulators and repealing Directive 91/157/EEC, Strasbourg, 6 September 2006.

2. EBRA, European Battery Recycling Association, 2008. http://www. ebrarecycling.org. 
3. Cui, J.; Zhang, L. (2008) Metallurgical recovery of metals from electronic waste: A review. J. Hazard. Mater., 158: 228-256.

4. Sayilgan, E.; Kukrer, T.; Civelekoglu, G.; Ferella, F.; Akcil, A.; Veglio, F.; Kitis, M. (2009) A review of technologies for the recovery of metals from spent alkaline and zinc-carbon batteries. Hydromettalurgy, 97: 158-166.

5. De Michelis, I.; Ferella, F.; Karakaya, E.; Beolchini, F.; Veglio, F. (2007) Recovery of zinc and manganese from alkaline and zinccarbon spent batteries. J. Power Sources, 172: 975-983.

6. Ferella, F.; De Michelis, I.; Veglio, F. (2008) Process for the recycling of alkaline and zinc-carbon spent batteries. J. Power Sources, 183: 805-811.

7. Shin, S.M.; Senanayake, G.; Sohn, J.-S.; Kang, J.-G.; Yang, D.-H.; Kim, T.-H. (2009) Separation of zinc from spent zinc-carbon batteries by selective leaching with sodium hydroxide. J. Hazard. Mater., 96: 349-353.

8. Sayilgan, E.; Kukrer, T.; Yigit, N.O.; Civelekoglu, G.; Kitis, M. (2010) Acid leaching and precipitation of zinc and manganese from spent battery powders using various reductants. J. Hazard. Mater., 173: $137-143$

9. Provazi, K.; Campos, B.A.; Espinosa, D.C.R.; Tenório, J.A.S. (2011) Metal separation from mixed types of batteries using selective precipitation and liquid-liquid extraction techniques. Waste Manage, 31: 59-64.

10. Buzatu, T.; Popescu, G.; Birloaga, I.; Saceanu, S. (2012) Study concerning the recovery of zinc and manganese from spent batteries by hydrometallurgical processes. Waste Manage. (in press) http:// dx.doi.org/10.1016/j.wasman.2012.10.005

11. Vatistas, N.; Bartolozzi, M.; Arras, S. (2001) The dismantling of the spent alkaline zinc maganese dioxide batteries and the recovery of the zinc from the anodic material. J. Power Sources, 101: 182-187.

12. Souza, C.C.B.M.; Tenório, J.A.S. (2004) Simultaneous recovery of zinc and manganese dioxide from household alkaline batteries through hydrometallurgical processing. J. Power Sources, 136: 191-196.

13. Devi, N.B.; Nathsarma, K.C.; Chakravortty, V. (1997) Extraction and separation of $\mathrm{Mn}$ (II) and $\mathrm{Zn}$ (II) from sulfate solutions by sodium salt of CYANEX 272. Hydromet., 45: 169-179.

14. Salgado, A.L.; Veloso, A.M.O.; Pereira, D.D.; Gontijo, G.S.; Salum, A.; Mansur, M.B. (2003) Recovery of zinc and manganese from spent alkaline batteries by liquid-liquid extraction with Cyanex 272. J. Power Sources, 115: 367-373.

15. El-Nadi, Y.A.; Daoud, J.A.; Aly, H.F. (2007) Leaching and separation of zinc from the black paste of spent $\mathrm{MnO}_{2}-\mathrm{Zn}$ dry cell batteries. J. Hazard. Mater., 143: 328-334.

16. Lee, J.Y.; Pranolo, Y.; Zhang, W.; Cheng, C.Y. (2010) The recovery of zinc and manganese from synthetic spent-battery leach solutions by solvent extraction. Solvent Extr. Ion Exch., 28: 73-84.

17. Rickelton, W.A.; Boyle, R.J. (1990) The selective recovery of zinc with new thiophosphinic acids. Solvent Extr. Ion Exch., 8: 783-797.

18. Rickelton, W.A.; Boyle, R.J. (1988) Solvent extraction with organophosphines-commercial and potential applications. Sep. Sci. Technol., 23: 1227-1250.

19. Caravaca, C.; Cobo, A.; Alguacil, F.J. (1994) Considerations about the recycling of EAF flue dusts as source for the recovery of valuable metals by hydrometallurgical processes. Resour. Conserv. Recycl., 10: 35-41.
20. Sole, K.C.; Hiskey, J.B. (1992) Solvent extraction characteristics of thiosubstituted organophosphinic acid extractant. Hydromet., 30: 345-365.

21. Kumar, V.; Sahu, S.K.; Pandey, B.D. (2010) Prospects for solvent extraction processes in the Indian context for the recovery of base metals: A review. Hydromet., 103: 45-53.

22. Nakon, D.G. (2004) Preparation and use of organic extractant for recovery of metal ions from aqueous solutions. US Patent 6692709, Canopean Pty. Ltd.

23. Jha, M.K.; Kumar, V.; Bagchi, D.; Singh, R.J.; Lee, J. (2007) Processing of rayon waste effluent for the recovery of zinc and separation of calcium using thiophosphinic extractant. Journal of Hazardous Materials, 145: 221-226.

24. Morin, D.; Lips, A.; Pinches, T.; Huisman, J.; Frias, C.; Norberg, A.; Forssberg, E. (2006) BioMine-Integrated project for the development of biotechnology for the metal-bearing materials in Europe. Hydrometallurgy, 83: 69-76.

25. Falco, L.; Thomas, H.; Curutchet, G. (2011) Indirect bioleaching of zinc and manganese from spent alkaline battery by Acidithiobacillus thioxidans cultured in an air lift bioreactor. International Conference on New Horizons in Biotechnology, Trivandrum, India.

26. Olson, G.J.; Brierley, J.A.; Brierley, C.L. (2003) Bioleaching review Part B: Progress in bioleaching: Applications of microbial processes by the minerals industries. Appl. Microbiol. Biotechnol., 63: 249-257.

27. Cerruti, C.; Curutchet, G.; Donati, E. (1998) Bio-dissolution of spent nickel-cadmium batteries using Thiobacillus ferrooxidans. J. Biotechnol., 62: 209-219.

28. Curutchet, G.; Tedesco, P.; Donati, E. (1996) Combined degradation of covellite by Thiobacillus ferrooxidans and Thiobacillus thiooxidans. Biotechnol. Lett., 18: 1471-1476.

29. Pogliani, C.; Curutchet, G.; Donati, E. (1997) Bioleaching of sulphide ore by a combined attack with two species of Thiobacilli. In: Fifth Southern Hemisphere Meeting on Mineral Technology. Seyfer S.R.L. Buenos Aires; pp 253-256.

30. Steudel, R. (1989) On the nature of the "Elemental sulphur" produced by sulphur oxidising bacteria: A model for S globules. In: Biology of Autotrophic Bacteria; Schlegel and Bowien, eds.; Science Tech. Publ., Ch. 16, p. 289.

31. Montgomery, D.C. (2001) Design and Analysis of Experiments, 5th Ed.; John Wiley \& Sons: New York.

32. Box, G.E.P.; Hunter, W.G.; Hunter, J.S. (1978) Statistics for Experiments: An Introduction to Design, Data Analysis and Model Building; John Wiley \& Sons: New York.

33. Gonzalez, A.G. (1998) Two level factorial experimental designs based on multiple linear regression models: A tutorial digest illustrated by case studies. Anal. Chim. Acta., 360: 227-241.

34. Da'na, E.; Sayari, A. (2011) Optimization of copper removal efficiency by adsorption on amine-modified SBA-15: Experimental design methodology. Chem. Eng. J., 167: 91-98.

35. Muzic, M.; Sertiæ-Bionda, K.; Gomzi, Z. (2010) A design of experiments investigation of adsorptive desulfurization of diesel fuel. Chem. Biochem. Eng. Q., 24: 253-264.

36. Bezerra, M.A.; Santelli, R.E.; Oliveira, E.P.; Villar, L.S.; Escaleira, L.A. (2008) Response surface methodology (RSM) as a tool for optimization in analytical chemistry. Talanta 76: 965-977.

37. Cheng, C.Y.; Boddy, G.; Zhang, W.; Godfrey, M.; Robinson, D.J.; Pranolo, Y.; Zhu, Z.; Wang, W. (2010) Recovery of nickel and cobalt from laterite leach solutions using direct solvent extraction: Part 1: Selection of a synergistic SX system. Hydrometallurgy, 104: 45-52. 